\title{
Potassium and Zinc in Relation to Improve Flax Varieties Yield and Yield Components as Grown under Sandy Soil Conditions
}

\author{
Bakry Ahmed Bakry1, Osama Anour Nofal'2, Mohamed Soliman Zeidan1, \\ Mahmoud Hozayn 1 \\ ${ }^{1}$ Field Crops Department, National Research Centre, Cairo, Egypt \\ ${ }^{2}$ Plant Nutrition Department, National Research Centre, Cairo, Egypt \\ Email: bakry ahmed2004@yahoo.com
}

Received 14 December 2014; accepted 10 January 2015; published 24 January 2015

Copyright (C) 2015 by authors and Scientific Research Publishing Inc.

This work is licensed under the Creative Commons Attribution International License (CC BY).

http://creativecommons.org/licenses/by/4.0/

(c) (i) Open Access

\begin{abstract}
Two field experiments were carried out at the experimental station of National Research Centre, Al-Nubaria District, El-Behira Governorate, Egypt during winter seasons of 2011/2012 and $2012 / 2013$ to study the effect of potassium soil application at the rates $(0,50,75$ and $100 \mathrm{~kg} / \mathrm{fed}$.) with or without chelated zinc foliar application $5 \%$ at the rate of $(0.03 \mathrm{~kg} / \mathrm{fed}$.) on the yield and quality of two flax varieties (Sakha-2 and Amon) in newly reclaimed sandy soil. The obtained results could be summarized as follow: Sakha-2 variety significantly surpassed Amon in plant height, technical length, number of branches/plant, seed yield/plant, straw yield/plant, 1000 seed weight, seed yield/fed., straw yield/fed., fiber \%, fiber yield/fed. and oil yield/fed. Amon variety surpassed Sakha-2 in fruiting zone length, number of capsules/plant and oil \% in both seasons. Potassium soil application at the rate of $(100 \mathrm{~kg} / \mathrm{fed}$.) with chelated zinc foliar application $5 \%$ at the rate of $(0.03 \mathrm{~kg} / \mathrm{fed}$.) gave the highest value for all studied characters.
\end{abstract}

\section{Keywords}

Flax, Potassium Fertilizer, Zinc Fertilizer

\section{Introduction}

Egypt vitally needs sustained agricultural development to cope with the social and economic obligations that are the normal consequences of the contributed high rates of population growth. This urgent need requires continu- 
ously scientifically based implementation of both vertical and horizontal schemes for more effective agricultural practices.

Flax is a source of two products; flax seed for oil and fiber for linen products. In Egypt, it is on old economic crop grown as a dual purpose crop for seeds and fibers which are used for the manufacture of linen. Production could be increased through the cultivation of high yielding cultivars and appropriate agronomic practices, among which fertilization is the most important.

Generally, the plants response to K fertilizers might be due to the soils with high fixing capacity [1]; the soil texture is sandy intensive cropping system, the introduction of high yielding varieties, the increment in nitrogen doses are applied in crop management [2] and [3]. In this connection, [4] concluded planting Giza-8 as flax seed variety for production seed and oil yields however, sowing vaiking variety as fiber flax variety for fiber yield production when they fertilized by $\mathrm{KNO}_{3}$ foliar application under sandy soil conditions.

Concerning micronutrients i.e. Fe, $\mathrm{Mn}$ and $\mathrm{Zn}$, [5] cleared that the availability of micronutrients is much affected by $\mathrm{pH}, \mathrm{CaCO}_{3}$ content, organic matter and soil texture [6].

[7] studied the effect of micronutrients on flax yield and quality. [8] concluded that $\mathrm{Zn}$ foliar application was important to correct the nutrient balance in flax plant (Sakha-2) undesirable soil conditions.

Many in ventilators reported significant differences among flax varieties [4] [9]-[11].

The objective of this investigation was to study the effect of potassium soil application and zinc foliar application of two flax varieties on yield and quality traits under sandy soil conditions.

\section{Materials and Methods}

A field experiment was carried out at the experimental Station of National Research Centre, Al-Nubria District El-Behira Governorate-Egypt, during the two successive winter seasons of 2011/2012 and 2012/2013. The soil of both experiment sites $(0-30 \mathrm{~cm})$ were newly reclaimed sandy soils where mechanical and chemical analysis is reported in Table 1.

The aim of this work was to investigate the effect of zinc foliar application and potassium sulfate soil application on yield and its components of flax (Linum usitatissimum L.) varieties (Sakha-2 and Amon) grown under newly reclaimed sandy soil. The experimental design was split plot design with four replicates, which flax varieties occupy the main plots and potassium sulfate treatments at rates of (0,50, 75 and $100 \mathrm{~kg} / \mathrm{fed}$.) with or with

Table 1. Mechanical and chemical analyses of the experimental site.

\begin{tabular}{|c|c|c|c|c|}
\hline Properties & & Year & 2011/2012 & 2012/2013 \\
\hline \multicolumn{5}{|l|}{ Mechanical analysis } \\
\hline Sand (\%) & & & 91.20 & 92.33 \\
\hline Silt (\%) & & & 03.70 & 02.95 \\
\hline Clay (\%) & & & 05.10 & 04.78 \\
\hline Soil texture & & & Sandy & Sandy \\
\hline \multicolumn{5}{|l|}{ Chemical analysis } \\
\hline pH (1:8.5 water) & & & 07.40 & 07.50 \\
\hline E.C. $(\mathrm{mmhos} / \mathrm{cm})$ & & & 00.30 & 00.50 \\
\hline $\mathrm{CaCO}_{3}(\%)$ & & & 01.40 & 01.65 \\
\hline Organic matter \% & \multirow{2}{*}{$\mathrm{P}$} & \multirow{6}{*}{$\mathrm{mg} / 100 \mathrm{~g}$ soil } & 00.30 & 00.24 \\
\hline Available P ppm & & & 00.22 & 00.24 \\
\hline \multirow[t]{8}{*}{ Exchangeable K ppm } & \multirow{4}{*}{$\begin{array}{l}\mathrm{K} \\
\mathrm{Ca} \\
\mathrm{Mg} \\
\mathrm{Na}\end{array}$} & & 10.18 & 12.00 \\
\hline & & & 92.00 & 90.00 \\
\hline & & & 18.04 & 18.00 \\
\hline & & & 12.36 & 15.02 \\
\hline & $\mathrm{Fe}$ & & 04.92 & 03.99 \\
\hline & $\mathrm{Mn}$ & $\mathrm{mg} / \mathrm{Kg}$ soil & 03.95 & 03.15 \\
\hline & $\mathrm{Zn}$ & & 00.13 & 00.04 \\
\hline & $\mathrm{Cu}$ & & 00.10 & 00.08 \\
\hline
\end{tabular}


out chelated zinc foliar application (5\%) at the rate of $1.5 \mathrm{~g} / \mathrm{l}(0.03 \mathrm{~kg} / \mathrm{fed}$.) were allocated at random in subplots. Seeds of flax varieties (Sakha-2 and Amon) were sown on the $17^{\text {th }}$ November in both season in rows 3.5 meters long, the distance between rows was $20 \mathrm{~cm}$ apart, Plot area was $10.5 \mathrm{~m}^{2}$ (3.0 m in width and $3.5 \mathrm{~m}$ in length). The recommended agricultural practices of growing linseed were applied and the seeding rate was 2000 seeds $\left./ \mathrm{m}^{2}\right)$. Pre-sowing, $150 \mathrm{~kg} / \mathrm{fed}$. of calcium super phosphate $\left(15.5 \% \mathrm{P}_{2} \mathrm{O}_{5}\right)$ was applied to the soil. Nitrogen was applied after emergence in the from of ammonium nitrate $33.5 \%$ at rate of $75 \mathrm{~kg} / \mathrm{fed}$. was applied at five equal doses before the $1^{\text {st }}, 2^{\text {nd }}, 3^{\text {rd }}, 4^{\text {th }}$ and $5^{\text {th }}$ irrigation. Irrigation was carried out using the new sprinkler irrigation system where water was added every 5 days.

Flax plants were foliar sprayed with chelated zinc $5 \%$ at rate of $1.5 \mathrm{~g} / \mathrm{l}(0.03 \mathrm{~kg} / \mathrm{fed}$.) In both seasons, foliar application of zinc was carried out twice; the plants were sprayed after 45 and 60 days from sowing. Flax plants were pulled when signs of full maturity were appeared, then left on ground to suitable complete drying. Capsules were removed carefully. At harvest the following characters were recorded on random samples of 10 guarded plants in each plot to estimate the following characters:

1. Fiber yield and its related characters:

- Plant height $(\mathrm{cm})$

- Straw yield/plant (g)

- Biological yield/ (ton/fed.)

- Technical stem length (cm)

- Fiber yield/plant (g)

- Fiber (g)

- Fiber yield (kg/fed.) = straw yield (kg/fed.) after retting multiplied by fiber

2. Seed yield and its related characters:

- Number of fruiting branches/plant

- Number of capsules/plant

- Fruiting zone length $(\mathrm{cm})$

- Seed yield/plant

- 1000 seed weight (g)

- Seed yield (kg/fed.)

- Seed oil \%: was determined by sox let apparatus using petroleum ether $\left(4^{\circ} \mathrm{C}-60^{\circ} \mathrm{C}\right.$ b.p) according to the Official Method [12].

- Oil yield (kg/fed.) was calculated by seed yield (kg/fed.) *Seed oil

Data were statistically analyzed separately for each season. The combined analysis was conducted for the data of the two seasons according [13], the least significant differences (LSD) was used to compare between means.

\section{Results and Discussion}

\section{A) Effect of flax varieties on growth characters}

At can be seen from Table 2 that yield and yield components of the studied varieties differed significantly in all characters under this trials.

Sakha-2 variety surpassed Amon variety in seed yield (587.9 kg/fed.) and oil yield (220.38 kg/fed.). The superiority of this variety may be due to the highest values of numbers of branches/plant (2.56) and seed yield/plant (0.34).

Similar results were previously obtained by [4] [10] [14] [15] and who reported that the flax cultivars differed in seed yield productivity.

Sakha-2 variety significantly exceeded Amon variety in straw yield (3.19 ton/fed.) and fiber yield (424.48 $\mathrm{kg} / \mathrm{fed}$.). These results may be attributing to the highest value of plant height $(87.85 \mathrm{~cm})$, technical length $(75.00$ $\mathrm{cm}$ ) and fiber \% (13.23). These results are in agreement with these obtained by [4] [9]-[11] and, they showed that there were large differences in straw yield and its components among flax genotypes. These results indicated that the variability among Sakha- 2 and Amon varieties which may be expected due to the difference of these varieties in origin, growth habit, the high diversity in genetic constituent and the environmental conditions of investigated cultivars under sandy soils.

\section{B) Effects of potassium (K) and zinc (Zn) on morphological characters}

The results given in Table 3 indicate dearly that morphological characters, yield and yield components of flax at harvest were significantly affected levels of potassium and zinc.

The same table shows that the mean values of studied characters of plants tend to increase with increasing ( $\mathrm{K}$ levels from 0, 50, 75, $100 \mathrm{~kg} / \mathrm{fed}$.) and $\mathrm{Zn}$ treatments from $\left(\mathrm{Zn}, \mathrm{K}_{1}+\mathrm{Zn}, \mathrm{K}_{2}+\mathrm{Zn}, \mathrm{K}_{3}+\mathrm{Zn}\right)$. The highest values 
Table 2. Effect of flax varieties on seed straw, oil fiber yields and there components (combined 2011/2012 and 2012/2013 seasons).

\begin{tabular}{|c|c|c|c|}
\hline Varieties & Sakha-2 & Amon & $\mathbf{L S D}_{0.05}$ \\
\hline Plant height $(\mathrm{cm})$ & 87.85 & 66.21 & 2.15 \\
\hline Technical length (cm) & 75.0 & 50.30 & 5.33 \\
\hline Fruiting zone length (cm) & 12.85 & 15.91 & 0.47 \\
\hline Number of capsules/plant & 11.41 & 11.62 & 0.11 \\
\hline Number of branches/plant & 0.54 & 2.42 & 0.03 \\
\hline Seed yield/plant (g) & 0.34 & 0.27 & 0.01 \\
\hline Straw yield/plant (g) & 1.47 & 1.11 & 0.13 \\
\hline 1000 seed weight (g) & 7.75 & 5.89 & 0.51 \\
\hline Seed yield (kg/fed.) & 587.9 & 468.91 & 31.45 \\
\hline Straw yield (ton/fed.) & 3.19 & 2.10 & 0.45 \\
\hline Fiber (\%) & 13.23 & 10.77 & 1.12 \\
\hline Fiber yield (kg/fed.) & 424.48 & 228.71 & 71.55 \\
\hline Oil (\%) & 37.36 & 37.81 & 0.17 \\
\hline Oil yield (kg/fed.) & 220.38 & 177.72 & 6.87 \\
\hline
\end{tabular}

Table 3. Effect of potassium fertilization with or without zinc foliar application on seed, straw, oil and fiber yield and there components (combined 2011/2012 and 2012/2013 seasons).

\begin{tabular}{|c|c|c|c|c|c|c|c|c|c|}
\hline \multirow{2}{*}{ Treatments } & \multirow{2}{*}{ Control } & \multicolumn{3}{|c|}{ Potassium (kg/fed.) } & \multirow{2}{*}{$\begin{array}{r}\text { Zinc (Zn) } \\
(1.5 \text { g/l) }\end{array}$} & \multicolumn{3}{|c|}{ Potassium with zinc } & \multirow{2}{*}{$\mathbf{L S D}_{0.05}$} \\
\hline & & $K_{1}(50)$ & $\mathbf{K}_{2}(\mathbf{7 5})$ & $K_{3}(100)$ & & $\mathbf{K}_{1}+\mathbf{Z n}$ & $\mathbf{K}_{2}+\mathbf{Z n}$ & $\mathbf{K}_{3}+\mathbf{Z n}$ & \\
\hline Plant height $(\mathrm{cm})$ & 69.94 & 75.22 & 76.31 & 78.89 & 73.33 & 79.75 & 80.58 & 82.23 & 2.05 \\
\hline Technical length (cm) & 56.93 & 60.35 & 61.75 & 64.19 & 59.92 & 64.97 & 65.68 & 67.45 & 1.18 \\
\hline Fruiting zone length (cm) & 13.01 & 14.88 & 14.56 & 14.70 & 13.42 & 14.78 & 14.91 & 14.79 & 1.04 \\
\hline Number of capsules/plant & 8.41 & 10.08 & 11.21 & 11.93 & 9.58 & 13.34 & 13.75 & 13.84 & 1.28 \\
\hline Number of branches/plant & 2.06 & 2.34 & 2.35 & 2.61 & 2.35 & 2.53 & 2.66 & 2.97 & 0.51 \\
\hline Seed yield/plant (g) & 0.17 & 0.24 & 0.30 & 0.34 & 0.24 & 0.36 & 0.38 & 0.40 & 0.21 \\
\hline Straw yield/plant (g) & 0.80 & 1.06 & 1.24 & 1.50 & 1.15 & 1.34 & 1.56 & 1.66 & 0.25 \\
\hline 1000 seed weight (g) & 6.19 & 6.85 & 6.92 & 6.96 & 6.76 & 6.97 & 7.00 & 7.08 & 0.16 \\
\hline Seed yield (kg/fed.) & 453.15 & 520.58 & 529.73 & 539.29 & 494.19 & 552.24 & 564.96 & 573.12 & 31.03 \\
\hline Straw yield (ton/fed.) & 2.20 & 2.47 & 2.69 & 2.78 & 2.31 & 2.84 & 2.91 & 2.95 & 0.19 \\
\hline Fiber (\%) & 9.60 & 11.34 & 12.49 & 12.64 & 11.17 & 12.87 & 12.91 & 12.99 & 0.15 \\
\hline Fiber yield (kg/fed.) & 217.87 & 290.47 & 343.51 & 358.05 & 262.44 & 371.5 & 380.84 & 388.12 & 12.22 \\
\hline Oil (\%) & 34.07 & 36.75 & 38.01 & 38.72 & 36.53 & 38.72 & 38.87 & 39.03 & 1.05 \\
\hline Oil yield (kg/fed.) & 153.74 & 181.01 & 201.23 & 208.95 & 180.26 & 213.93 & 219.63 & 223.64 & 5.31 \\
\hline
\end{tabular}


of plant height technical length, fruiting zone length were obtained with $\mathrm{K}$ at the rate $100 \mathrm{~kg} / \mathrm{fed}$. with $\mathrm{Zn}$ at the rate (5\%). This may be referred to the rate of $\mathrm{Zn}$ in biosynthesis of the natural axine, indole acetic acid [16] and account promotion of stem elongation [17] indicated the positive effect of micronutrients on growth and flax plant. In addition, the role of $\mathrm{K}$ information of carbohydrate, proteins, photosynthesis translocation regulation, enzyme action [18].

C) Effect of potassium and zinc yield and yield components

It is visible from Table 3 that number of capsules/plant, number of branches/plant, seed yield/plant, straw yield/plant, 1000-seed weight, seed yield/fed., straw yield/fed., fiber \%, fiber yield/fed. oil \% and oil yield/fed. were significantly increased by potassium and $\mathrm{Zn}$ treatments.

The number of branches/plant was reached the highest increase due to the treatment of highest potassium application and $\mathrm{Zn}$ foliar application $\left(\mathrm{K}_{3}+\mathrm{Zn}\right)$. In this connection, it is worthily to note that trace elements were reported to control the hormonal balanced of the plant [19] in addition, [4] indicated that all potassium sources were significantly affected in all plant studied characteristics except technical length .

Table 3 illustrate that the increase on seed flax yield/plant and fed. were significantly and this results may be due to the treatment $\left(\mathrm{K}_{3}+\mathrm{Zn}\right)$ in both seasons which [20] reported that plants can't take up their micronutrients requirements under undesirable soil conditions. Such as high $\mathrm{pH}$, low organic matter content (Table 1). These increases of flax yield/plant and fed. may be attributed to the effect of micronutrients, on dry matter or due to the greet efficiency of enzyme activities which affected plant pigments and at the rate of photosynthesis. The same results with cotton plants reported by [21]-[24] presented that application of zinc increased seed/yield and oil yield as well as total unsaturated fatty acids (Oleic and Linoleic) content in cotton. On the other hand, [18] indicated that these effects for the treatment, $\mathrm{K}_{3}+\mathrm{Zn}$ may be due to the role $\mathrm{K}$ in plant such as synthesis of nucleic acid, chlorophyll, oxidative, photospherylation and translocation of solutions [18].

Data presented in Table 3 exhibit that seed oil\% was significantly increased by addition the highest rate of potassium with zinc foliar application $\left(\mathrm{K}_{3}+\mathrm{Zn}\right)$. The same finding has occurred by [8] [25] with Zn, where [10] and [4] with (K).

The high level of $\mathrm{K}$ application with $\mathrm{Zn}$ foliar application $\left(\mathrm{K}_{3}+\mathrm{Zn}\right)$ significantly increased seed yield/fed. by $20.93 \%$, straw yield/fed. by $25.42 \%$ and oil \% by $12.71 \%$ over the control. In this connection, [8] suggested that $\mathrm{Zn}$ foliar application can improve seed yield of flax seed. Also, [4] cleared the importance of $\mathrm{K}$ increasing the flax production.

Data presented in Table 3 pointed out that treatment of K especially high dose with $\mathrm{Zn}$ gave a positive effect of all the studied characteristics of flax plant. These results may be due to the improving of physiological performance in tested plants due to more nutrients uptake by plants from soil. Such results are in harmony with those obtained by [17] [26].

D) Effect of potassium and zinc on fiber yield

According to the above mentioned results in Table 3 cleared that fiber yield and fiber \% were affected significantly with all treatments especially by application at the highest rate with Zn foliar application in both seasons may be due to the role of $\mathrm{Zn}$ on fundamental metabolic reaction and acceleration protein synthesis [25] and the role of $\mathrm{K}$ in formation of carbohydrates, protein, photosynthesis translocation regulation and translocation of solutions [18].

E) Interaction effect

Results in Table 4 showed that there was significant affect of interaction between the flax varieties, potassium and zinc fertilization on yield and yield components.

$\mathrm{K}_{3}+\mathrm{Zn}$ treatment recorded superiority among all the treatments with flax varieties. The greatest straw yield (1.9 ton/fed.) and fiber yield (492.83 kg/fed.) were obtained when sowing Sakha-2 var. and treated the plants by $\left(\mathrm{K}_{3}+\mathrm{Zn}\right)$ fertilizer. This was due to the obtained highest values of plant height (94.51), fruiting zone length $(14.85 \mathrm{~cm})$, straw yield/plant $(1.91 \mathrm{~g})$ and fiber \% (13.91). While the best results of oil \% (37.10) was achieved by Amon variety was due to highest values of fruiting zone length $(17.06 \mathrm{~cm})$ and number of capsules/plant (14.10).

\section{Conclusion}

Eventually, it could be concluded that the studied growth and yield characters response significantly to the investigated factors. Shaka-2 variety showed its superiority to the most characters under study, whereas Amon 
Table 4. The effect of interaction between the flax varieties and potassium and zinc fertilization on seed, straw, oil and fiber yields and there components (combined 2011/2012 and 2012/2013 seasons).

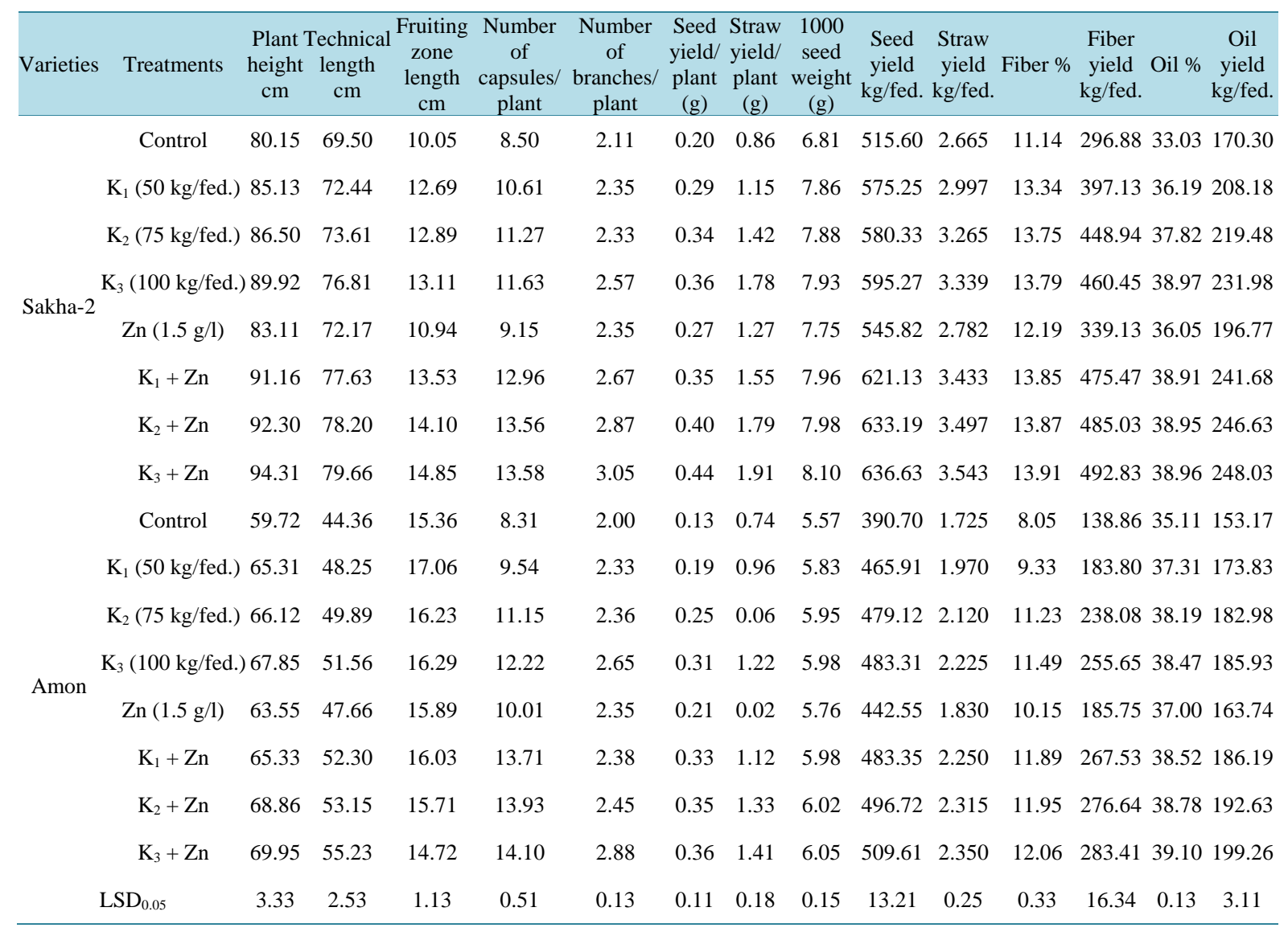

variety surpassed the other in a few cases. The combination between the highest rate of potassium and $\mathrm{Zn}$ foliar application gave in most cases the best results for the studied characters. It seemed evident that the fertilization with the highest rate of potassium sulphate (100 kg/fed.) with Zn foliar application at rate of (5\%) gave the best result with all the varieties.

\section{References}

[1] Page, A.L., Binglam, F.T., Ganje, T.J. and Garber, M.J. (1963) Availability and Fixation of Added Potassium in Two California Soils When Cropped to Cotton. Soil Science Society of America, Proceedings, 27, 323-326.

[2] Oosterhuis, D.M., Miley, W.N., Maples, R. and Wallschleger, S.D. (1991) Foliar Fertilization with Potassium Nitrate in Cotton. Beltwide Cotton Conferences, San Antonic, 8-12 January, 942.

[3] Tupper, G.R., Ebelhar, M.W. and Peringle, H.C. (1991) Potassium and Nitrogen Rate Interaction. Beltwide Cotton Conferences, San Antonic, 8-12 January, 925-927.

[4] Bakry, A.B., Nofal, O.A. and Zeidan, M.S. (2012) Agronomic Characteristics of Three Flax Varieties as Affected by Source of Potassium Fertilization under Newly Reclaimed Sandy Soil Conditions. Austration Journal of Basic and Applied Sciences, 6, 77-81.

[5] Amberger, A. (1991) Importance of Micronutrients for Crop Production under Semiarid Condition of North Africa and Middle East. Proceedings of 4th Micronutrients Workshop, Amman, February 1989, 5-30.

[6] Moawed, E.A. (2001) Effect of Micronutrients and New Distances on the Yield of Some Flax (Linum usitatissimum L.) Varieties. Egyptian Journal of Applied Sciences, 16, 157-172.

[7] Mostafa, S.H. and Deep, E.I. (2003) Response of Flax and Quality to Seeding Rates and Micronutrients. Alexandria Journal of Agricultural Research, 24, 425-442.

[8] Nofal, O.A., Zedian, M.S. and Bakry, B.A. (2011) Flax Yield and Quality Traits as Affected by Zinc Foliar Applica- 
tion under Newly Reclaimed Sandy Soils. Journal of Applied Sciences Research, 7, 1361-1367.

[9] El-Hariri, D.M., El-Sweify, A.H. and Mostafa, S.H. (1996) Response of Flax Yield to Cultivars, Phytohormone Level and Pulling Dates. Proceedings of 4th European Reg. Workshop on Flax, FAO, Rouen, 25-28.

[10] El-Hariri, D.M., Mostafaand, S.H. and El-Sweify, A.H. (1998) Effect of Potassium Fertilizer and Phytohormone Level on Yield Attributes, Yield and Quality of Flax in Sandy Soil. The 1st Nordic Conference on Flax and Hemp. Processing, St. Petersburg, 28-30 September 1998, 69-76.

[11] El-Hariri, D.M., Hassanien, M.S. and El-Sweify, A.H. (2004) Evaluation of Same Flax Genotype Straw Yield, Yield Components and Technological Characters. Journal of Natural Fibers, 1, 1-12.

[12] AOAC (1980) Official Methods of the Association of Official of Official Analytical Chemists. 11th Edition, Rockville.

[13] Gomez, K.A. and Gomez, A.A. (1984) Statistical Procedures for Agriculture Research. 2nd Edition, John Wiley and Sons, New York, 180.

[14] Gaffer, S.M., Hella, A.M. and Sahsan, A.I. (1985) Coperative Studies on Growth and Yield of Some Flax Varieties. Annals of Agricultural Sciences, Moshtohor, 23, 1483-1492.

[15] Sarour, S.Gh.R., Abou-Khadrah, S.H., Youssef, S.A., El-Kady, E.A.F. and Gazzar, A.A. (1992) Effect of Planting Pattern and Seeding Rate on Growth Yield and Quality of Some Flax Varieties. Proceedings of 5th Conference Agron. Zagazig, 2, 836-850.

[16] Mengel, K. and Kirkby, A. (1987) Chapter 16: Copper. In: Mengel, K., Kirkby, E.A., Kosegarten, H. and Appel, T., Eds., Principles of Plant Nutrition, 4th Edition, International Potash Institute, Bern, 537-549.

[17] El-Shahawy, T.A., Rokiek, K.G., Belbaa, L.K. and Abbas, S.M. (2008) Micronutrients, B-Vitamins and Yeast in Relation to Increasing Flax (Linum usitissimum L.) Growth Yield Productivity and Controlling Associated Weeds. Asian Journal of Agricultural Research, 2, 1-14. http://dx.doi.org/10.3923/ajar.2008.1.14

[18] Pandy, S.N. and Sinha, B.R. (1978) Plant Physiological. Chapter 6, 2nd Revised Edition, 115-120.

[19] Coke, L. and Whittington, W.J. (1968) The Role of Boron in Plant Growth: IV. Interrelationships between Boron and Indol-3YL-Acetic Acid in the Metabolism of Boron Radicals. Journal of Experimental Botany, 19, 295-308. http://dx.doi.org/10.1093/jxb/19.2.295

[20] Sillanpaa, M. (1982) Micronutrients and Nutrient Status of Soils: A Global Study (Soils Bulletin). FAO, Rome, 48289.

[21] Amberger, A. (1974) Micronutrients Dynamics in the Soil and Function in Plant Metabolism. Proceedings of 1st Workshop of Egypt Botany Society, Cairo, 1974, 81-90.

[22] Hegab, A.A.T., Mahgoub, M.A. and Yossef, A.E. (1987) Effect of Iron, Manganese and Zinc on Yield. Cotton Grade and Quality of Fiber Properties of Egyptian Cotton. Agricultural Research Review, 65, 645.

[23] Eid, E.T., Abdel-Al., M.H., Ismail, M.S. and Wassel, O.M.M. (1997) Response of Egyptian Cotton to Potassium and Micronutrient Application. Proceedings of FAO-IRCRNC. Joint Meeting of the IRCRNC Working Groups on Cotton Nutrition and Growth Regulators in Cotton, Cairo, 20-23 March 1995, 139-145.

[24] Sawan, Z.M., Hafez, S.A. and Basyony, A.E. (2001) Effect of Phosphorus Fertilization and Foliar Application of Chelated Zinc and Calcium on Seed-Protein and Oil Yields and Oil Properties of Cotton. Journal of Agricultural Science, 136, 191-198. http://dx.doi.org/10.1017/S0021859601008644

[25] Abdel Shafy, M.A., El-Menshawy, M.E. and Girgis, E.A. (2001) Effect of Some Macro and Micronutrients Fertilization on Cotton Yield. Minofiya Journal of Agricultural Research, 26, 673-687.

[26] Fazwi, A.F.A. (1991) Micronutrients Effect on Field Crops in Egypt. In: El-Fouly, M.M. and Fazwi, A.F.A., Eds., Proceedings of 4th Micronutrients Workshop, Amman, February 1989, 75. 
Scientific Research Publishing (SCIRP) is one of the largest Open Access journal publishers. It is currently publishing more than 200 open access, online, peer-reviewed journals covering a wide range of academic disciplines. SCIRP serves the worldwide academic communities and contributes to the progress and application of science with its publication.

Other selected journals from SCIRP are listed as below. Submit your manuscript to us via either submit@scirp.org or Online Submission Portal.
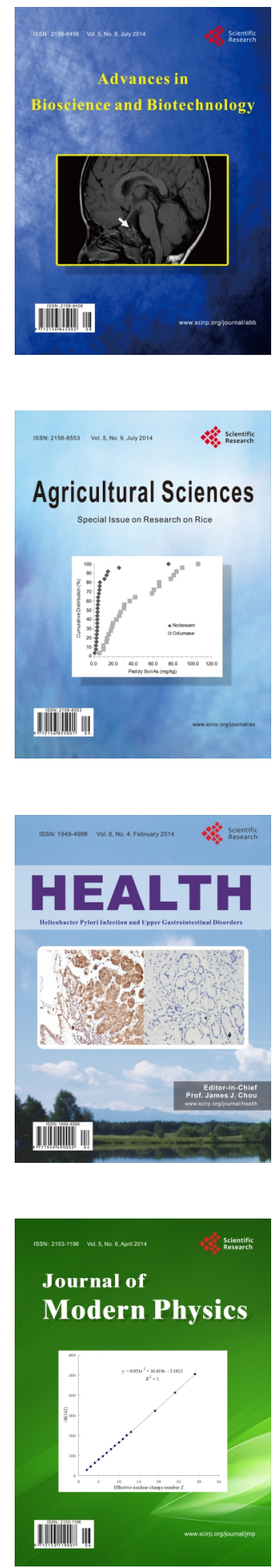
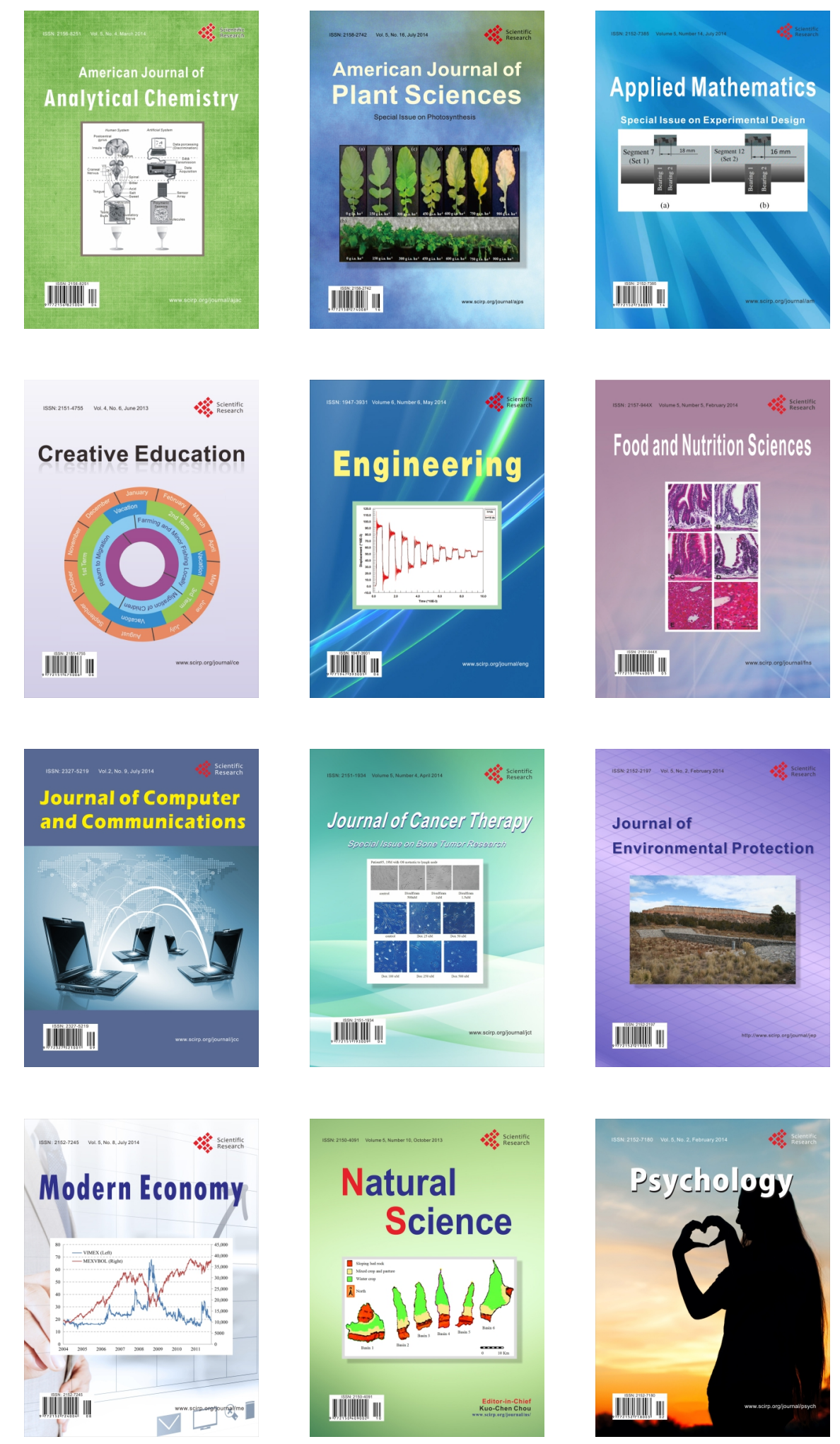